\title{
Refining and End Use Study of Coal Liquids
}

\author{
Topical Report \\ October 1997
}

Work Performed Under Contract No.: DE-AC22-93PC91029

For

U.S. Department of Energy

Office of Fossil Energy

Federal Energy Technology Center

P.O. Box 880

Morgantown, West Virginia 26507-0880

By

Bechtel Corporation

9801 Washington Boulevard

Gaithersburg, Maryland 20878-5356 


\section{Disclaimer}

This report was prepared as an account of work sponsored by an agency of the United States Government. Neither the United States Government nor any agency thereof, nor any of their employees, makes any warranty, express or implied, or assumes any legal liability or responsibility for the accuracy, completeness, or usefulness of any information, apparatus, product, or process disclosed, or represents that its use would not infringe privately owed rights. Reference herein to any specific commercial product, process, or service by trade name, trademark, manufacturer, or otherwise does not necessarily constitute or imply its endorsement, recommendation, or favoring by the United States Government or any agency thereof. The views and opinions of authors expressed herein do not necessarily state or reflect those of the United States Government or any agency thereof. 


\section{DISCLAIMER}

Portions of this document may be illegible in electronic image products. Images are produced from the best available original document. 


\section{Table of Contents}

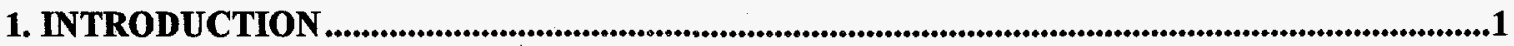

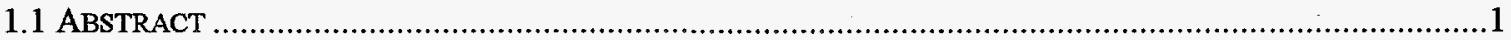

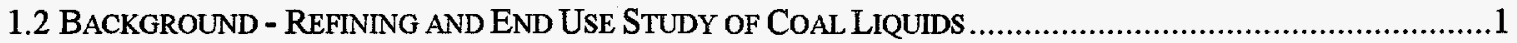

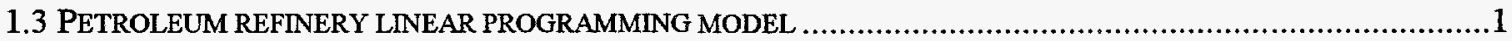

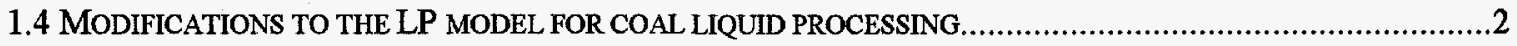

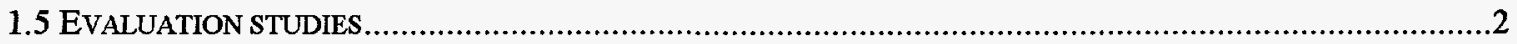

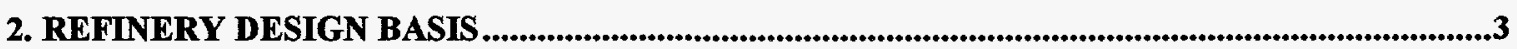

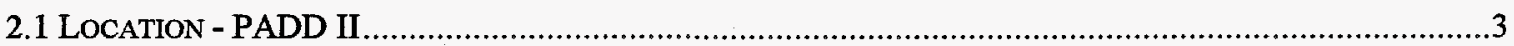

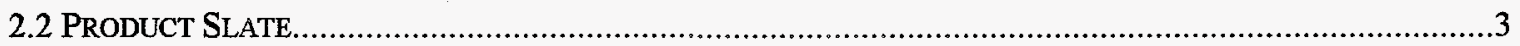

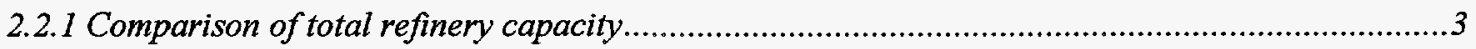

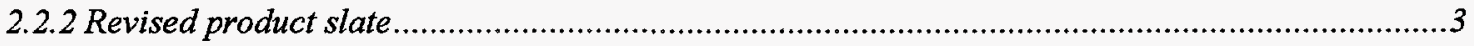

2.3 PROJECTED CONVENTIONAI/REFORMULATED GASOLINE RATIO .........................................................

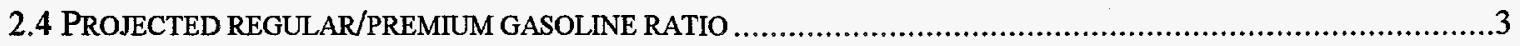

3. DIRECT COAL LIQUID DESIGN BASIS ...................................................................................11

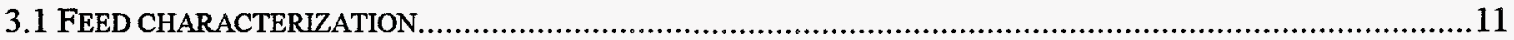

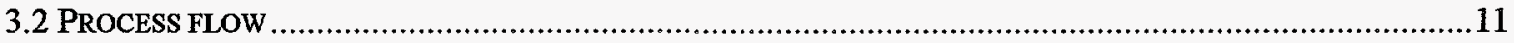

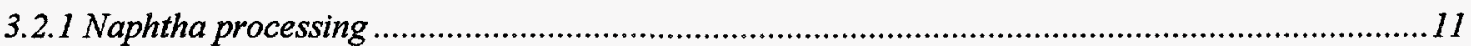

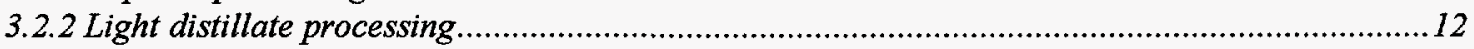

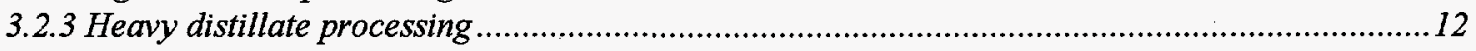

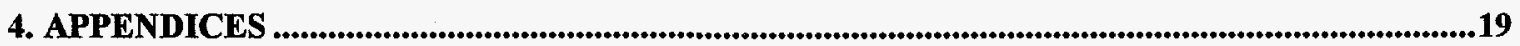

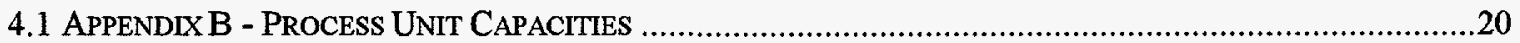

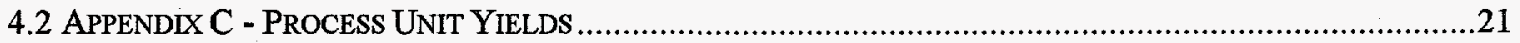

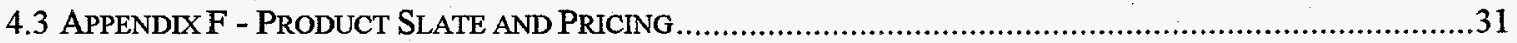




\section{Introduction}

\subsection{Abstract}

This report summarizes revisions to the design basis for the linear programing refinery model that is being used in the Refining and End Use Study of Coal Liquids. This revisions primarily reflect the addition of data for the upgrading of direct coal liquids.

\subsection{Background - Refining and End Use Study of Coal Liquids}

Bechtel National Inc., with Southwest Research Institute, Amoco Oil R\&D, and The M.W. Kellogg Co. as subcontractors, initiated a study on November 1, 1993, for the U.S. Department of Energy's (DOE's) Federal Energy Technology Center (FETC) to determine the most cost effective combination of upgrading processes needed to make high quality, liquid transportation fuels from petroleum crude and direct and indirect coal liquefaction products in an existing petroleum refinery.

A key objective is to determine the most desirable ways of integrating coal liquefaction liquids into existing petroleum refineries to produce transportation fuels meeting current and future, e.g. year 2000, Clean Air Act Amendment (CAAA) standards. An integral part of the above objectives is to test the fuels or blends produced and compare them with established ASTM fuels. The comparison will include engine tests to ascertain compliance of the fuels produced with CAAA and other applicable fuel quality and performance standards.

The final part of the project includes a detailed economic evaluation of the cost of processing the coal liquids to their optimum products. The cost analyses is for the incremental processing cost; in other words, the feed is priced at zero dollars. The study reflects costs for operations using state of the art refinery technology; no capital costs for building of new refineries are considered. Some modifications to the existing refinery may be required. Economy of scale dictates the minimum amount of feedstock that should be processed.

\subsection{Petroleum refinery linear programming model}

In 1995, a model was developed for use in the PIMS (Process Industry Modeling System) linear programming (LP) software to simulate a generic Midwest/PADD II (Petroleum Administration for Defense District II) petroleum refinery of the future.

This "petroleum-only" version of the model establishes the size and complexity of the refinery after the year 2000 and prior to the introduction of coal liquids. It should be noted that no assumption has been made on when a coal liquefaction plant can be built to produce coal liquids except that it will be after the year 2000 . The year 2000 was chosen because it is the latest year where fuel property and emission standards have been set by the Environmental Protection Agency. It assumes the refinery has been modified to 1) accept crudes that are heavier in gravity and higher in sulfur than today's average crude mix and 2) meet future product fuel specifications. This model will be used as a basis for determining the optimum scheme for processing coal liquids in a petroleum refinery.

A topical report ${ }^{1}$ was issued which summarizes the design basis for this petroleum refinery LP

1 Topical report "Petroleum Refinery Linear Programming Model Design Basis", Refining and End Use Study of Coal Liquids, March, 1995 
model.

\subsection{Modifications to the LP model for coal liquid processing}

This topical report/addendum supplements the design basis for the petroleum refinery LP model. The primary focus of this addendum is to provide the design basis for direct coal liquid processing in the model. (Due to budgetary concerns, work on the indirect liquid has been suspended.)

In the Refining and End Use Study, two direct coal liquids, POC-1 and POC-2, are being evaluated. POC-1 (referred to as DL1 in this study) was produced from Eastern bituminous coal in the Hydrocarbon Technologies, Inc. (HTI) coal liquefaction system without the use of the in-line hydrotreater. POC-2 (referred to as DL2 in this study) was produced from Western coal in the same system, but with the use of the in-line hydrotreater.

The primary source of the data on these two liquids for this design basis was produced in Task 2 Feed Characterization and Task 4 - Pilot Plant Testing of the Basic Program. In addition, this addendum summarizes changes to the petroleum refinery model. These revisions were primarily based on Task 4 data on petroleum feed materials.

Key topics covered in this addendum are:

- Revised product slate based on new energy consumption forecast

- Direct coal liquid characterization data

- Description of the LP model coal liquid processing schemes

- Process unit yields for petroleum and coal liquid feeds based on Task 4 pilot plant test data

\subsection{Evaluation studies}

The results of various evaluation studies will be provided in the final report on the Option 1 section of this study. 


\section{Refinery design basis}

\subsection{Location - PADD II}

The Petroleum Administration for Defense District II (PADD II) was selected as the basis for the location and product marketing for the generic midwestern refinery used in the LP model. This area encompasses 14 central U.S. states and has 35 refineries with a total refining capacity of approximately 3.4 million barrels per calendar day (bpcd). These 35 refineries range in size from 4,000 bpcd to $410,000 \mathrm{bpcd}$. Tables 2-1 and 2-2 summarizes the capacity and location of the PADD II refineries.

\subsection{Product Slate}

Since energy consumption data was not available specifically for PADD II, data for determining the product slate for the refinery model was based on a DOE Energy Information Administration report ${ }^{2}$.

This report summarizes energy consumption by U.S. Census Divisions. These divisions are smaller and do not coincide with the PADD districts. However, by combining U.S. Census Divisions 3, 4 and 6, an area approximately equal to PADD II can be obtained. The exceptions are the states Oklahoma, Alabama and Mississippi. The U.S. Census Divisions do not include Oklahoma, but include Alabama and Mississippi. The combined refining capacity data for U.S. Census Divisions 3, 4 and 6 are shown in Tables 2-3 and 2-4.

\subsubsection{Comparison of total refinery capacity}

A comparison of Tables 2-1 and 2-3 show that the total refining capacity difference between the combined U.S. Census Divisions and PADD II is small (1.5\%) and should not impact the LP model results.

\subsubsection{Revised product slate}

The EIA report provides an estimate of future energy consumption for each of the U.S. Census Divisions in quads per year $\left(10^{15}\right.$ btu/year). For the three divisions (No. 3, 4, and 6) representing the PADD II region, the energy consumptions were totaled and are summarized in Table 2-5. These rates were then converted to barrels per day (bpsd) and normalized to a 150,000 bpsd crude feed rate. The revised product slate is shown in Table F-1 of the Appendix

\subsection{Projected conventional/reformulated gasoline ratio}

The split between conventional and reformulated gasoline was previously assumed to be $60 / 40$ on a volume basis. Based on the EIA projections for the year 2000 (shown in Table 2-6), the production ratio between conventional and reformulated gasolines was revised to $75 / 25$.

\subsection{Projected regular/premium gasoline ratio}

The ratio between regular and premium gasoline was previously assumed to be 60/40. Table 2-7 shows the ratio of regular and premium gasoline consumption for 1995 in PADD II. Approximately $25 \%$ of the PADD II market was for premium and mid-grade gasolines. The

2 "Supplement to the Annual Energy Outlook 1995", Department of Energy/Energy Information Agency, February, 1995, DOE/EIA-0554(95) 
regular/premium gasoline ratio was revised to $75 / 25^{3}$.

${ }^{3}$ Hart's 21 st Century Fuels, November, 1995 
Table 2-1 PADD II Refinery Total Capacities

\begin{tabular}{|c|c|c|}
\hline States & No. of refineries & Total crude capacity, bpcd \\
\hline Michigan & 4 & 125,200 \\
\hline Ohio & 4 & 466,400 \\
\hline Indiana & 3 & 435,990 \\
\hline Kentucky & 2 & 224,800 \\
\hline Tennessee & 1 & 90,000 \\
\hline Wisconsin & 1 & 33,200 \\
\hline Illinois & 6 & 906,550 \\
\hline Minnesota & 2 & 314,000 \\
\hline Missouri & 0 & 0 \\
\hline North Dakota & 1 & 58,000 \\
\hline South Dakota & 0 & 0 \\
\hline Nebraska & 0 & 0 \\
\hline Kansas & 4 & 302,950 \\
\hline Oklahoma & 7 & 417,900 \\
\hline Total & 35 & $3,374,990$ \\
\hline
\end{tabular}


Table 2-2 Comparison of Refinery Crude Capacity by State - PADD II

\begin{tabular}{|c|c|c|c|c|c|}
\hline \multicolumn{6}{|c|}{ No. of refineries with crude capacity, bpcd } \\
\hline State & $<50,000$ & $\begin{array}{c}50,000 \text { to } \\
90,000\end{array}$ & $\begin{array}{c}90,001 \text { to } \\
200,000\end{array}$ & $\begin{array}{c}200,001 \text { to } \\
300,000\end{array}$ & $>300,000$ \\
\hline Michigan & 3 & 1 & & & \\
\hline Ohio & & 1 & 3 & & \\
\hline Indiana & 2 & & & & 1 \\
\hline Kentucky & 1 & & & 1 & \\
\hline Tennessee & & 1 & & & \\
\hline Wisconsin & 1 & & & & \\
\hline Illinois & & 2 & 2 & 2 & \\
\hline Minnesota & & 1 & & 1 & \\
\hline \multicolumn{6}{|l|}{ Missouri } \\
\hline North Dakota & & 1 & & & \\
\hline South Dakota & & & & & : \\
\hline \multicolumn{6}{|l|}{ Nebraska } \\
\hline Kansas & & 3 & 1 & & \\
\hline Oklahoma & 3 & 4 & & & \\
\hline Total & 10 & 14 & 6 & 4 & 1 \\
\hline
\end{tabular}


Table 2-3 U.S. Census Divisions 3, 4 \& 6 Refining Capacity

\begin{tabular}{|l|c|c|c|}
\hline States & No. of refineries & $\begin{array}{c}\text { Total crude } \\
\text { capacity, bpcd }\end{array}$ & $\begin{array}{c}\text { Division - } \\
\text { Description }\end{array}$ \\
\hline Michigan & 4 & 125,200 & 3-East North Central \\
\hline Ohio & 3 & 466,400 & 3-East North Central \\
\hline Indiana & 1 & 435,990 & 3-East North Central \\
\hline Wisconsin & 6 & 33,200 & 3-East North Central \\
\hline Illinois & 2 & 906,550 & 3-East North Central \\
\hline Kentucky & 1 & 224,800 & 6-East South Central \\
\hline Tennessee & 3 & 90,000 & 6-East South Central \\
\hline Alabama & 4 & 130,000 & 6-East South Central \\
\hline Mississippi & 2 & 336,800 & 6-East South Central \\
\hline Minnesota & 0 & 314,000 & 4-West North Central \\
\hline Missouri & 1 & 0 & 4-West North Central \\
\hline North Dakota & 0 & 58,000 & 4-West North Central \\
\hline South Dakota & 0 & 0 & 4-West North Central \\
\hline Nebraska & 35 & 0 & 4-West North Central \\
\hline Iowa & 0 & $3,423,890$ & 4-West North Central \\
\hline Kansas & & $4-$ West North Central \\
\hline Total & 4 & & \\
\hline
\end{tabular}


Table 2-4 Comparison of Refinery Crude Capacity by State - U.S. Census Divisions 3, 4 \& 6

\begin{tabular}{|c|c|c|c|c|c|}
\hline \multirow[b]{2}{*}{ State } & \multicolumn{5}{|c|}{ No. of refineries with crude capacity, bpcd } \\
\hline & $<50,000$ & $\begin{array}{c}50,000 \text { to } \\
90,000\end{array}$ & $\begin{array}{l}90,001 \text { to } \\
200,000\end{array}$ & $\begin{array}{c}200,001 \text { to } \\
300,000\end{array}$ & $>300,000$ \\
\hline Michigan & 3 & 1 & & & \\
\hline Ohio & & 1 & 3 & & \\
\hline Indiana & 2 & & & & 1 \\
\hline Kentucky & 1 & & & 1 & \\
\hline Tennessee & & 1 & & & \\
\hline Wisconsin & 1 & & & & \\
\hline Illinois & & 2 & 2 & 2 & \\
\hline Minnesota & & 1 & & 1 & \\
\hline Missouri & & & & & \\
\hline North Dakota & & 1 & & & \\
\hline South Dakota & & & & & \\
\hline Nebraska & & & & & \\
\hline Kansas & & 3 & 1 & & \\
\hline Iowa & & & & & \\
\hline Alabama & 2 & 1 & & & \\
\hline Mississippi & 3 & & & 1 & \\
\hline Total & 12 & 11 & 6 & 5 & 1 \\
\hline
\end{tabular}


Table 2-5 Projected Fuel Consumption for the Year 2000 for U.S. Census Divisions 3, 4 and $6^{4}$

\begin{tabular}{|l|c|c|c|}
\hline & \multicolumn{3}{|c|}{ Projected } \\
\hline & Quads/yr & bpcd/ref & \multicolumn{1}{c|}{$\%$} \\
\hline Gasoline & 4.638 & 113,407 & 62.55 \\
\hline Kerosene/Jet & 0.658 & 15,007 & 8.28 \\
\hline No. 2 Fuel Oil & 0.694 & 15,303 & 8.44 \\
\hline Diesel & 1.577 & 34,774 & 19.18 \\
\hline Residual Fuel & 0.138 & 2,819 & 1.56 \\
\hline Subtotal & & 181,310 & 100.00 \\
\hline & & & \\
\hline Petro Coke \& Asphalt & 1.109 & 22,503 & \\
\hline Total Includ. Coke \& Asphalt & & 203,813 & \\
\hline
\end{tabular}

4 "Supplement to the Annual Energy Outlook 1995", Department of Energy/Energy Information Agency, February, 1995, DOE/EIA-0554(95) 


\section{Table 2-6 Percentage Market Share for Gasoline Types by Census Divisions for Year $2000^{5}$}

\begin{tabular}{|l|c|c|c|}
\hline Gasoline Type & Division 3 & Division 4 & Division 6 \\
\hline Traditional & $76 \%$ & $74 \%$ & $92 \%$ \\
\hline Oxygenated (2.7\% oxygen) & $0 \%$ & $26 \%$ & $1 \%$ \\
\hline Reformulated (2.0\% oxygen) & $24 \%$ & $0 \%$ & $7 \%$ \\
\hline
\end{tabular}

Table 2-7 Percentage Market Share for Gasoline Grades for June 1995 for PADD $\|^{6}$

\begin{tabular}{|l|c|c|}
\hline & U.S. Gallons & \% of Total Gasoline \\
\hline Regular & $2,307,043$ & 73.95 \\
\hline Mid Grade & 313,641 & 10.05 \\
\hline Premium & 499,179 & 16.00 \\
\hline Total & $3,119,863$ & 100.00 \\
\hline
\end{tabular}

5 "Supplement to the Annual Energy Outlook 1995", Department of Energy/Energy Information Agency, February, 1995, DOE/EIA-0554(95)

${ }^{6}$ Hart's 21st Century Fuels, November, 1995 


\section{Direct coal liquid design basis}

\subsection{Feed characterization}

To properly evaluate the coal liquids using the LP model, characterization data was required on the neat liquids and their fractionated cuts. This data is especially important if the neat cuts are used directly in product blending.

Characterization data for the DL1 and DL2 liquids was obtained in two steps. First, the whole liquids were measured for general properties such as specific gravity, sulfur content. Second, each liquid was then fractionated into four cuts; light naphtha $\left(\mathrm{C} 5-180^{\circ} \mathrm{F}\right)$, medium naphtha $(180-$ $\left.350^{\circ} \mathrm{F}\right)$, light distillate $\left(350-500^{\circ} \mathrm{F}\right)$, and heavy distillate $\left(500+^{\circ} \mathrm{F}\right)$.

The properties for the four coal liquid fractions are shown in Tables 3-1 to 3-4 for both liquids. These tables show only property data that was inputed into the model. Additional property data has been reported in various monthly and quarterly progress reports. As noted in these reports, the coal liquids are highly hydrogenated, desulfurized and denitrified.

\subsection{Process flow}

In the petroleum refinery LP model, each upgrading step (naphtha hydrotreating, catalytic cracking, etc.) is represented by a separate "submodel". Each of these submodels determine key parameters such as the feed material, volumetric yield, utilities, etc. for that particular upgrading step. For the coal liquids, new submodels were created. These submodels "process" only coal liquids and contain the process parameters pertaining to those coal liquid feeds.

The products from the sister petroleum and coal liquid submodels are mixed together before they can be further processed or blended into the required products. For example, the product from the petroleum naphtha hydrotreater is mixed with the product from the coal liquid naphtha hydrotreater. The reason that this is done is that the two submodels represent a single physical upgrading unit operating at a single operating condition. In this physical unit, the petroleum and coal liquids are co-fed and the product yields are based on this feed blend.

Table 3-5 identifies the petroleum and coal liquid submodels for the five upgrading steps that were tested in the Task 4 - Pilot Plant Testing program.

Figures 3-1 to 3-3 are block flow diagrams of the model showing the processing configuration for the coal liquid fractions.

\subsubsection{Naphtha processing}

Figure 3-1 depicts the processing schemes for the coal liquid naphthas. The light naphtha fraction is sent to the isomerization unit for octane improvement. The medium naphtha is hydrotreated to remove sulfur and nitrogen to 0.5 ppmw for reformer catalyst considerations. The treated medium naphtha is then dehexanized and sent to the reformer for octane improvement. The dehexanizer overhead containing benzene and benzene precursors is blended with the light naphtha for isomerization. As mentioned previously, the model has been configured so that the co-processing of petroleum and coal liquid is simulated.

The yield data shown in Tables C-6A, C-6B and C-6C show that the reformer yields are significantly higher for the two direct coal liquid naphthas than for the petroleum naphtha. These 
differences result in higher overall values for the direct coal liquids.

\subsubsection{Light distillate processing}

Figure 3-2 shows the processing scheme for the coal liquid light distillate. Both the DL1 and the DL2 light distillates have excellent sulfur and nitrogen properties. Since the DL2 liquid was more severely hydrogenated during production, its smoke point is slightly higher. Table $\mathrm{C}-2$ shows that hydrotreating the DL1 light distillate results in a small improvement in the smoke point (8.5 to 12.5 $\mathrm{mm}$ ), while there is no improvement in the smoke point of the DL2 light distillate.

\subsubsection{Heavy distillate processing}

Figure 3-3 shows the processing for the heavy distillate coal liquid. These distillates can be either sent to blending, to hydrotreating or to catalytic cracking (either directly or through the hydrotreater). Preliminary LP analysis showed that the slight improvement in FCC yield from hydrotreating the DL1 heavy distillate did not justify the costs of hydrotreating (increased capital expenditure, hydrogen, utilities, etc.). For this reason it was decided that conducting pilot plant hydrotreating tests on the DL2 heavy distillate was unnecessary. Therefore, the DL2 heavy distillate bypasses the hydrotreating unit and goes to cat cracking or blending directly. 


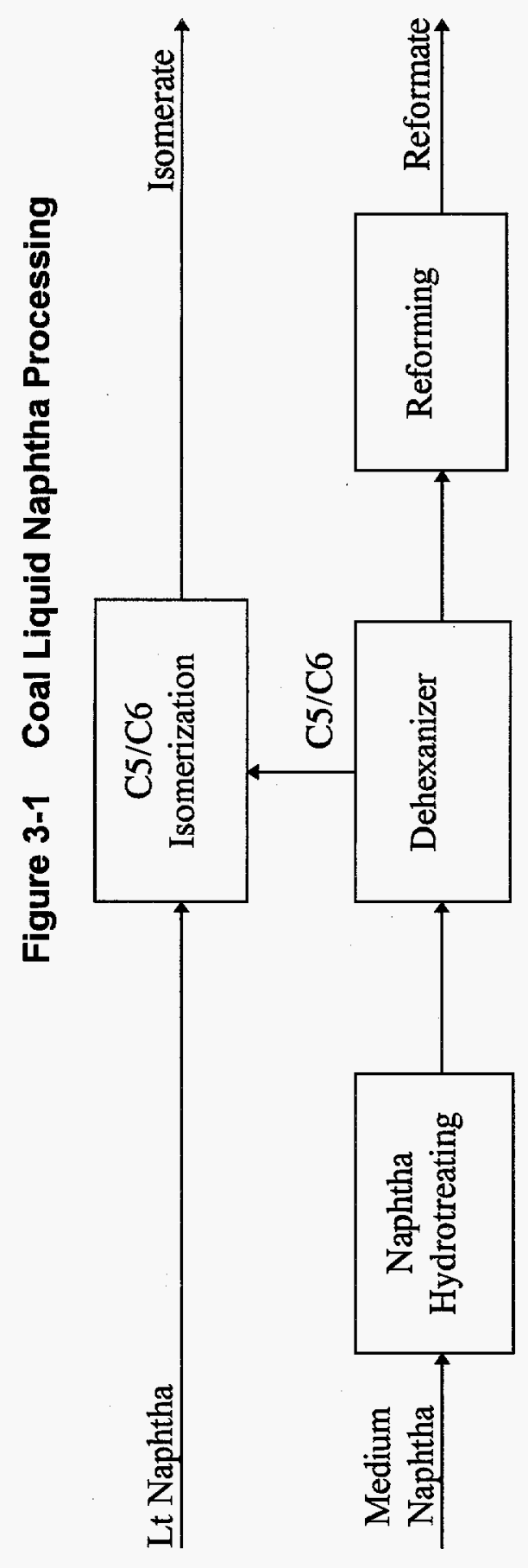




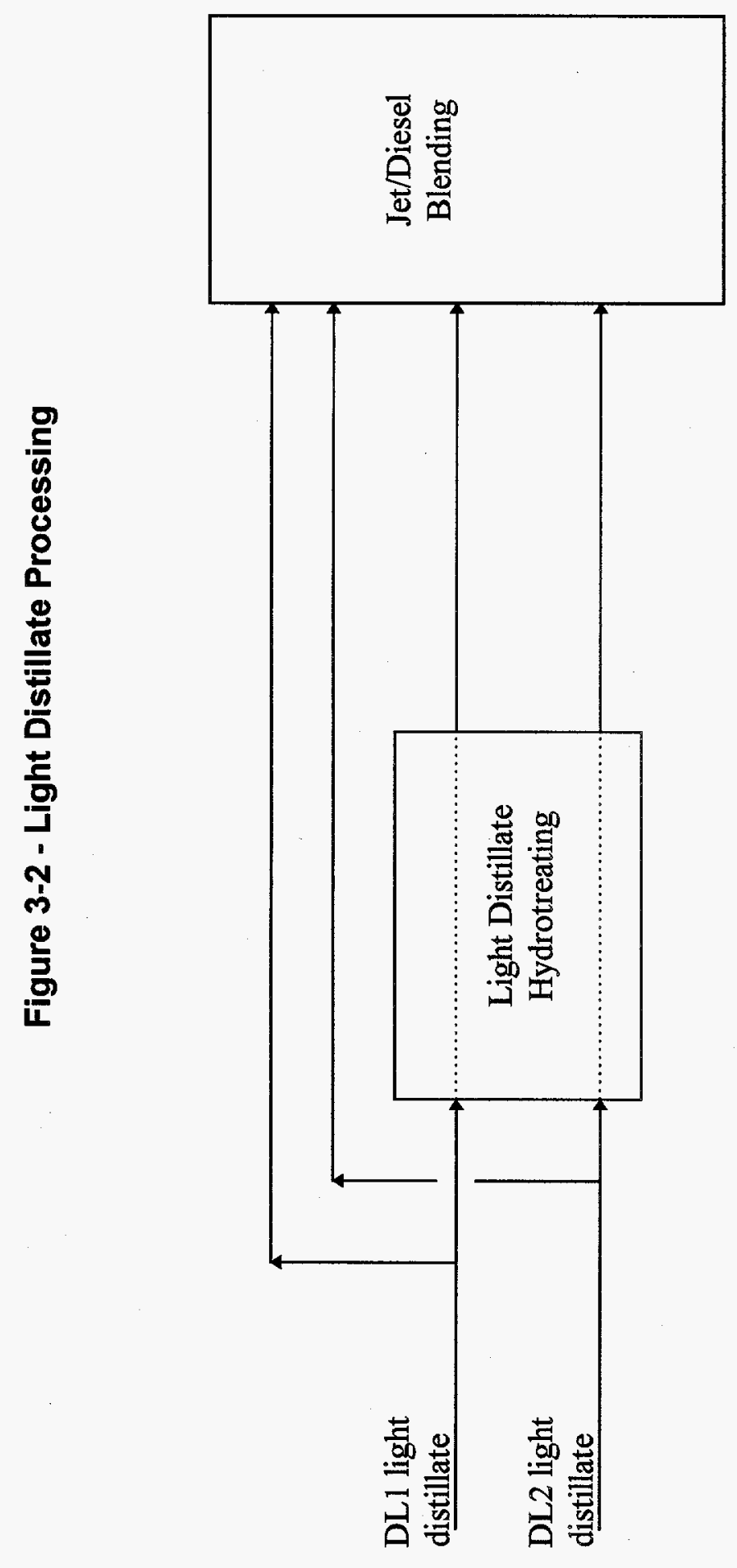




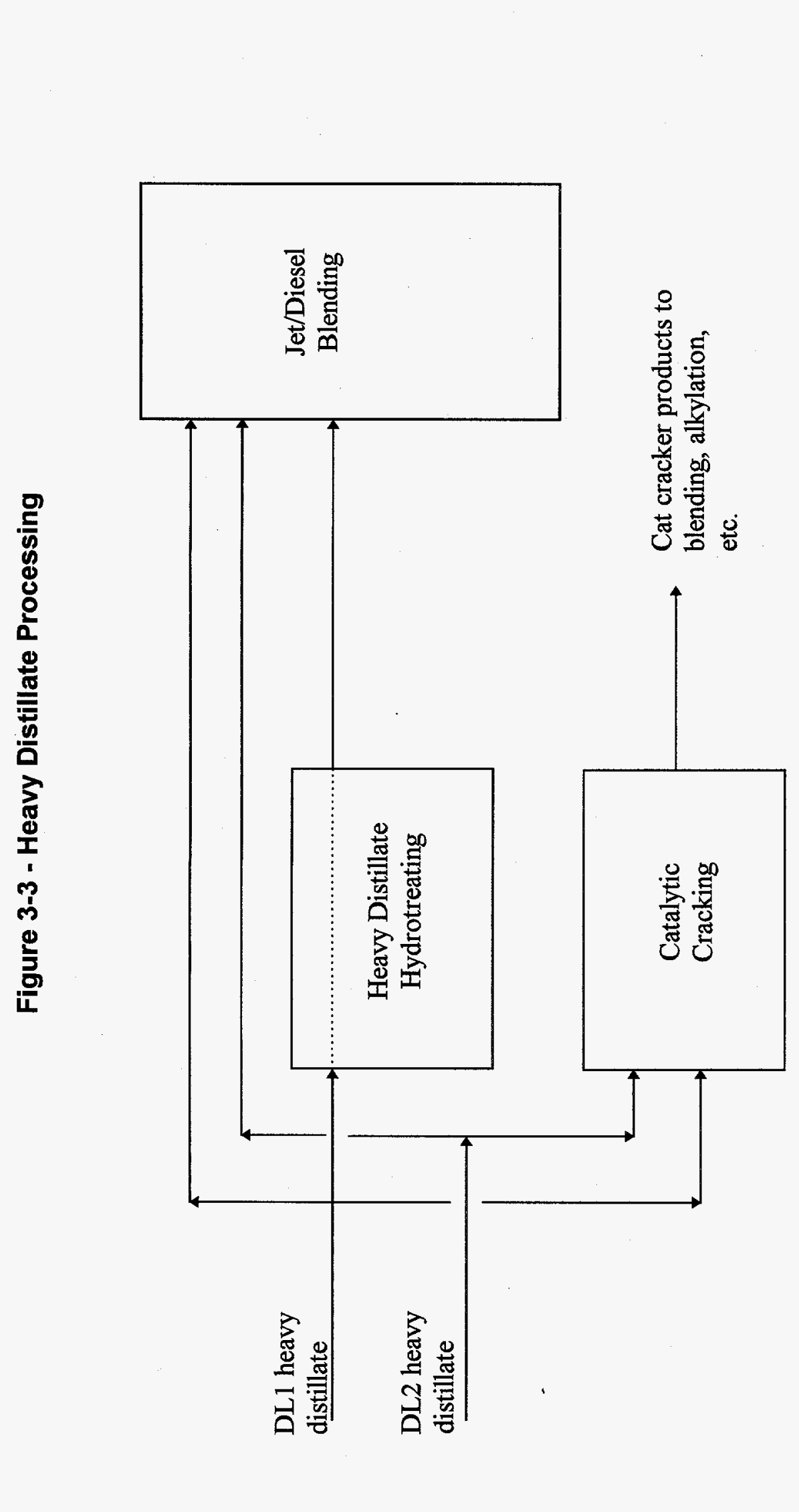


Table 3-1 Properties of DL1 \& DL2 Light Naphtha

\begin{tabular}{|l|c|c|}
\hline & DL1 & DL2 \\
\hline API & 64.7 & 60.6 \\
\hline Sulfur, wt\% & 0.015 & 0.004 \\
\hline Nitrogen, wt\% & 0.005 & $<1 \mathrm{ppm}$ \\
\hline Paraffins, vol\% & 92.9 & 97.2 \\
\hline Olefins, vol\% & 4.4 & 0.9 \\
\hline Aromatics, vol\% & 2.7 & 1.9 \\
\hline RON & 78 & - \\
\hline MON & 61.6 & - \\
\hline
\end{tabular}

Table 3-2 Properties of DL1 \& DL2 Medium Naphtha

\begin{tabular}{|l|c|c|}
\hline & DL1 & DL2 \\
\hline API & 46.7 & 49.7 \\
\hline Sulfur, wt\% & 0.069 & 0.005 \\
\hline Nitrogen, wt\% & 0.021 & $<1 \mathrm{ppm}$ \\
\hline Paraffins, vol\% & 83.0 & 91.9 \\
\hline Olefins, vol\% & 4.5 & 0.8 \\
\hline Aromatics, vol\% & 12.5 & 7.3 \\
\hline RON & 81 & $<60$ \\
\hline MON & 78 & $<60$ \\
\hline
\end{tabular}


Table 3-3 Properties of DL1 \& DL2 Light Distillate

\begin{tabular}{|l|c|c|}
\hline & DL1 & DL2 \\
\hline API & 30 & 32.3 \\
\hline Sulfur, wt\% & 0.023 & 0.001 \\
\hline Nitrogen, wt\% & 0.066 & 0.005 \\
\hline Paraffins, vol\% & 36.7 & 74.3 \\
\hline Olefins, vol\% & 4.6 & 1.7 \\
\hline Aromatics, vol\% & 58.7 & 24.0 \\
\hline Cetane Index & 25.0 & 27.8 \\
\hline Smoke Point, mm & 8.5 & 14.5 \\
\hline
\end{tabular}

Table 3-4 Properties of DL1 \& DL2 Heavy Distillate

\begin{tabular}{|l|c|c|}
\hline & DL1 & DL2 \\
\hline API & 22.3 & 23.3 \\
\hline Sulfur, wt\% & 0.021 & 0.002 \\
\hline Nitrogen, wt\% & 0.049 & 0.004 \\
\hline Paraffins, vol\% & 46.3 & 59.7 \\
\hline Olefins, vol\% & 2.4 & 3.5 \\
\hline Aromatics, vol\% & 51.3 & 36.8 \\
\hline Cetane Index & 34.7 & 34.2 \\
\hline Smoke Point, $\mathrm{mm}$ & 7.3 & 10.0 \\
\hline
\end{tabular}


Table 3-5 Submodel Summary

\begin{tabular}{|l|c|c|c|}
\hline & $\begin{array}{c}\text { Petroleum } \\
\text { Submodel }\end{array}$ & $\begin{array}{c}\text { DL1 } \\
\text { Submodel }\end{array}$ & $\begin{array}{c}\text { DL2 } \\
\text { Submodel }\end{array}$ \\
\hline Naphtha hydrotreating & SNHT & SNH2 & SNH2 \\
\hline Naphtha reforming & SLPR & SLP1 & SLP2 \\
\hline Light distillate hydrotreating & SKHT & SKH2 & SKH2 \\
\hline Heavy distillate hydrotreating & $\begin{array}{c}\text { SDHT, SDH2 } \\
\text { SDHS }\end{array}$ & SDH3 & none \\
\hline Catalytic cracking & SCCU & SCCU $^{1}$ & SCCU $^{1}$ \\
\hline
\end{tabular}

${ }^{1}$ For simplification purposes the catalytic cracking model handles both petroleum and coal liquid feeds. 


\section{Appendices}

The tables provided in Appendices B, C, and F were originally included in the topical report on the petroleum refinery model. These tables have been updated and/or revised to include the direct coal liquid upgrading data. The following updated tables are included:

- Appendix B - Process Unit Capacities - (Table B-1)

- Appendix C - Process Unit Yields -

Naphtha hydrotreating (Table C-1)

Light distillate/kerosene hydrotreating (Table C-2)

Heavy distillate hydrotreating (Tables C-3A,B)

Reforming (Tables C-6A,B,C)

Catalytic cracking (Tables C-7A,B,C)

- Appendix F - Product slate and prices - (Table F-1). 


\subsection{Appendix B - Process Unit Capacities}

Table B-1 - Unit capacities - 1993 and Base

\begin{tabular}{|l|c|c|}
\hline Plant & $\begin{array}{c}1993 \text { Base } \\
\text { Capacities, } \\
\text { Mbpsd }\end{array}$ & $\begin{array}{c}\text { Year 2000 Base } \\
\text { Capacities, } \\
\text { Mbpsd }\end{array}$ \\
\hline Atmospheric column & & 145.1 \\
\hline Vacuum column & & 67.0 \\
\hline Sulfuric acid alkylation & 12.0 & 12.4 \\
\hline Isomerization & 8.4 & 9.7 \\
\hline MTBE/TAME & 0.6 & 1.8 \\
\hline ETBE/TAEE & 0.0 & 0.0 \\
\hline Naphtha hydrotreater & 44.9 & 26.4 \\
\hline Kerosene hydrotreater & 6.0 & 9.6 \\
\hline Low severity cracked distillate hydrotreater & 11.6 & 6.0 \\
\hline High severity cracked distillate hydrotreater & 0.0 & 2.2 \\
\hline Low severity SR distillate hydrotreater & 19.0 & 24.7 \\
\hline Gas oil hydrotreater & 16.3 & 9.2 \\
\hline Atmospheric resid desulfurization & 0.0 & 2.0 \\
\hline Catalytic reformer & 38.6 & 24.4 \\
\hline Catalytic cracker & 54.2 & 54.6 \\
\hline Hydrocracker & 6.6 & 6.6 \\
\hline Delayed coker & 17.4 & 20.4 \\
\hline Depentanizer & & 35.0 \\
\hline Dehexanizer & $11 \mathrm{MMSCFD}$ & $16 \mathrm{MMSCFD}$ \\
\hline Hydrogen plant & & 162 LT/D \\
\hline Sulfur plant & & 26.5 \\
\hline & & \\
\hline
\end{tabular}




\subsection{Appendix C - Process Unit Yields}

The values shown in the following tables are the base yields for the given feed quality. For petroleum feeds these yields vary according to certain feed properties. For example, in the hydrotreaters the yield of hydrogen sulfide increases as the feed sulfur content increases. For coal liquid feeds, the yields and properties are fixed.

Table C-1 - Naphtha hydrotreating

\begin{tabular}{|c|c|c|c|}
\hline Feed & $\begin{array}{l}\text { SR \& coker } \\
\text { medium } \\
\text { naphtha }\end{array}$ & $\begin{array}{l}\text { DL1 coal } \\
\text { liquid }\end{array}$ & $\begin{array}{l}\text { DL2 coal } \\
\text { liquid }\end{array}$ \\
\hline Feed API & 54.0 & 46.7 & 49.7 \\
\hline Feed sulfur content, wt $\%$ & 1.43 & 0.069 & 0.005 \\
\hline$\%$ desulfurization & 99.9 & 99.99 & 99.99 \\
\hline Hydrogen, scf/bbl & 100 & 10 & 139 \\
\hline \multicolumn{4}{|l|}{ Product yields, vol $\%$ of feed } \\
\hline Hydrogen sulfide (FOE) & 0.44 & 0.02 & 0.00 \\
\hline Methane (FOE) & 0.06 & 0.06 & 0.06 \\
\hline Ethane (FOE) & 0.09 & 0.09 & 0.09 \\
\hline Propane & 0.06 & 0.06 & 0.06 \\
\hline N-Butane & 0.35 & 0.35 & 0.35 \\
\hline Naphtha & 99.2 & 99.70 & 99.64 \\
\hline \multicolumn{4}{|l|}{ Utilities, per bbl of feed } \\
\hline Fuel, MMBtu & 0.026 & 0.026 & 0.026 \\
\hline Power, KWH & 0.68 & 0.68 & 0.68 \\
\hline Steam, MLbs & 0.002 & 0.002 & 0.002 \\
\hline Cooling water, MGals & 0.001 & 0.001 & 0.001 \\
\hline Catalyst and chemicals, $\$$ & 0.019 & 0.019 & 0.019 \\
\hline
\end{tabular}


Table C-2 - Light distillate (kerosene) hydrotreating

\begin{tabular}{|c|c|c|c|}
\hline Feed & $\begin{array}{l}\text { SR Light } \\
\text { Distillate }\end{array}$ & $\begin{array}{l}\text { DL1 Light } \\
\text { Distillate }\end{array}$ & $\begin{array}{l}\text { DL2 Light } \\
\text { Distillate }\end{array}$ \\
\hline Feed API & 43.4 & 30.0 & 32.3 \\
\hline Feed sulfur content, wt $\%$ & 0.28 & 0.023 & 0.001 \\
\hline Feed smoke point, mm & 22.1 & 8.5 & 14.5 \\
\hline Product smoke point, $\mathrm{mm}$ & 22.1 & 12.5 & 14.5 \\
\hline$\%$ desulfurization & 90 & 99 & 99 \\
\hline Hydrogen, scf/bbl & 60 & 120 & 120 \\
\hline \multicolumn{4}{|l|}{ Product yields, vol $\%$ of feed } \\
\hline Hydrogen sulfide (FOE) & 0.08 & 0.01 & 0.00 \\
\hline Methane (FOE) & 0.20 & 0.22 & 0.22 \\
\hline Ethane (FOE) & 0.01 & 0.01 & 0.01 \\
\hline Propane & 0.02 & 0.03 & 0.03 \\
\hline N-Butane & 0.12 & & \\
\hline Naphtha & 0.45 & & \\
\hline Distillate & 99.30 & 100.08 & 100.08 \\
\hline \multicolumn{4}{|l|}{ Utilities, per bbl of feed } \\
\hline Fuel, MMBtu & 0.029 & 0.029 & 0.029 \\
\hline Power, KWH & 1.62 & 1.62 & 1.62 \\
\hline Steam, MLbs & 0.006 & 0.006 & 0.006 \\
\hline Cooling water, MGals & 0.003 & 0.003 & 0.003 \\
\hline Catalyst and chemicals, $\$$ & 0.038 & 0.038 & 0.038 \\
\hline
\end{tabular}


Table C-3A - Heavy distillate hydrotreating - petroleum

\begin{tabular}{|c|c|c|c|}
\hline Severity and feed type & $\begin{array}{l}\text { Low Severity } \\
\text { Distillate HDT - } \\
\text { Cracked Feed }\end{array}$ & $\begin{array}{l}\text { High Severity } \\
\text { Distillate HDT - } \\
\text { Cracked Feed }\end{array}$ & $\begin{array}{l}\text { Distillate HDT - SR } \\
\text { Distillate }\end{array}$ \\
\hline Feed API & 34.8 & 24.3 & 34.8 \\
\hline Feed sulfur content, wt $\%$ & 0.77 & 0.76 & 0.77 \\
\hline$\%$ desulfurization & 60 & 95.5 & 97 \\
\hline Hydrogen, scf/bbl & 100 & 330 & 125 \\
\hline \multicolumn{4}{|l|}{ Product yields, vol $\%$ of feed } \\
\hline Hydrogen sulfide (FOE) & 0.16 & 0.27 & 0.26 \\
\hline Methane (FOE) & 0.20 & 0.20 & 0.20 \\
\hline Ethane (FOE) & 0.01 & 0.01 & 0.01 \\
\hline Propane & 0.02 & 0.02 & 0.02 \\
\hline N-Butane & 0.15 & 0.6 & 0.18 \\
\hline Naphtha & 0.58 & 2.3 & 0.66 \\
\hline Distillate & 100.10 & 98.30 & 98.30 \\
\hline \multicolumn{4}{|l|}{ Utilities, per bbl of feed } \\
\hline Fuel, MMBtu & 0.031 & 0.031 & 0.031 \\
\hline Power, KWH & 1.767 & 1.767 & 1.767 \\
\hline Steam, MLbs & 0.007 & 0.007 & 0.007 \\
\hline Cooling water, MGals & 0.003 & 0.003 & 0.003 \\
\hline Catalyst and chemicals, $\$$ & 0.041 & 0.041 & 0.041 \\
\hline
\end{tabular}


Table C-3B - Heavy distillate hydrotreating - DL1 coal liquid

\begin{tabular}{|l|c|}
\hline Feed & DL1 heavy distillate \\
\hline Feed API & 22.4 \\
\hline Feed sulfur content, wt\% & 0.03 \\
\hline Feed cetane index & 34.0 \\
\hline Product cetane index & 35.6 \\
\hline \% desulfurization & 87 \\
\hline Hydrogen, scf/bbl & 212 \\
\hline & \\
\hline Product yields, vol\% of feed & \\
\hline & \\
\hline Hydrogen sulfide (FOE) & \\
\hline Methane (FOE) & 0.01 \\
\hline Ethane (FOE) & 0.23 \\
\hline Propane & 0.01 \\
\hline N-Butane & 0.04 \\
\hline Naphtha & 0.00 \\
\hline Distillate & 0.00 \\
\hline & 100.60 \\
\hline Utilities, per bbl of feed & \\
\hline Fuel, MMBtu & \\
\hline Power, KWH & 0.031 \\
\hline Steam, MLbs & 0.007 \\
\hline Cooling water, MGals & 0.003 \\
\hline Catalyst and chemicals, $\$$ & 0.041 \\
\hline & \\
\hline & \\
\hline & \\
\hline & \\
\hline & \\
\hline & \\
\hline & \\
\hline & \\
\hline & \\
\hline & \\
\hline & \\
\hline & \\
\hline
\end{tabular}


Table C-6A - Low pressure reforming - petroleum

\begin{tabular}{|l|c|c|c|c|}
\hline Severity level & 1 & 2 & 3 & 4 \\
\hline & & & & \\
\hline Feed API & 55.6 & 55.6 & 55.6 & 55.6 \\
\hline & & & & \\
\hline Product research octane & 88 & 92 & 96 & 100 \\
\hline Product yields, vol\% of feed & & & & \\
\hline Hydrogen (FOE) & 5.08 & 5.84 & 8.88 & 15.19 \\
\hline Methane (FOE) & 0.63 & 1.02 & 1.56 & 2.44 \\
\hline Ethane (FOE) & 1.32 & 2.05 & 3.02 & 4.38 \\
\hline Propane & 3.35 & 6.32 & 9.71 & 13.41 \\
\hline Iso-butane & 1.21 & 1.74 & 2.78 & 3.61 \\
\hline N-butane & 2.59 & 3.35 & 4.28 & 5.62 \\
\hline Reformate & 85.75 & 81.55 & 75.37 & 66.52 \\
\hline & & & & \\
\hline Utilities, per bbl of feed & & & & \\
\hline Fuel, MMBtu & 0.274 & 0.277 & 0.280 & 0.282 \\
\hline Power, KWH & 4.755 & 4.803 & 4.852 & 4.900 \\
\hline Steam, MLbs & 0.057 & 0.057 & 0.058 & 0.059 \\
\hline Cooling water, MGals & 0.089 & 0.090 & 0.091 & 0.092 \\
\hline Catalyst and chemicals, $\$$ & 0.083 & 0.083 & 0.084 & 0.085 \\
\hline
\end{tabular}


Table C-6B - Low pressure reforming - DL1 medium naphtha

\begin{tabular}{|l|c|c|c|c|}
\hline Severity level & 1 & 2 & 3 & 4 \\
\hline Feed API & & & & \\
\hline & 49.0 & 49.0 & 49.0 & 49.0 \\
\hline Product research octane & & & & \\
\hline Product yields, vol\% of feed & 88 & 92 & 96 & 100 \\
\hline Hydrogen (FOE) & & & & \\
\hline Methane (FOE) & 6.11 & 8.9 & 11.12 & 14.04 \\
\hline Ethane (FOE) & 0.08 & 0.22 & 0.47 & 2.03 \\
\hline Propane & 0.36 & 0.94 & 2.01 & 3.96 \\
\hline Iso-butane & 1.17 & 2.09 & 5.02 & 11.49 \\
\hline N-butane & 0.25 & 0.39 & 0.87 & 1.78 \\
\hline Reformate & 0.50 & 0.98 & 1.97 & 3.98 \\
\hline & 93.94 & 90.54 & 85.31 & 73.95 \\
\hline Utilities, per bbl of feed & & & & \\
\hline Fuel, MMBtu & & & & 0.09 \\
\hline Power, KWH & 0.057 & 0.057 & 0.058 & 0.059 \\
\hline Steam, MLbs & 0.083 & 0.083 & 0.084 & 0.092 \\
\hline Cooling water, MGals & & 0.277 & 0.280 & 0.282 \\
\hline Catalyst and chemicals, \$ & & & & \\
\hline
\end{tabular}


Table C-6C - Low pressure reforming - DL2 medium naphtha

\begin{tabular}{|l|c|c|c|c|}
\hline Severity level & 1 & 2 & 3 & 4 \\
\hline & & & & \\
\hline Feed API & 49.4 & 49.4 & 49.4 & 49.4 \\
\hline Product research octane & & & & \\
\hline Product yields, vol\% of feed & 88 & 92 & 96 & 100 \\
\hline Hydrogen (FOE) & & & & \\
\hline Methane (FOE) & 3.73 & 6.52 & 8.76 & 11.45 \\
\hline Ethane (FOE) & 0.00 & 0.01 & 0.29 & 1.27 \\
\hline Propane & 0.15 & 0.29 & 0.68 & 2.24 \\
\hline Iso-butane & 0.31 & 0.62 & 2.23 & 6.93 \\
\hline N-butane & 0.14 & 0.28 & 0.56 & 1.67 \\
\hline Reformate & 0.20 & 0.40 & 1.07 & 3.08 \\
\hline & 92.86 & 90.93 & 87.5 & 78.71 \\
\hline Utilities, per bbl of feed & & & & \\
\hline Fuel, MMBtu & & & & \\
\hline Power, KWH & 0.274 & .277 & .280 & .282 \\
\hline Steam, MLbs & 0.089 & 0.090 & 0.091 & 0.092 \\
\hline Cooling water, MGals & & 0.083 & 0.084 & 0.085 \\
\hline Catalyst and chemicals, \$ & & 0.057 & 0.058 & 0.059 \\
\hline
\end{tabular}


Table C-7A - Catalytic cracking - petroleum gas oil feed

\begin{tabular}{|l|c|c|}
\hline Reactor outlet temperature & 975 & 1010 \\
\hline Feed API & 26.4 & 26.4 \\
\hline & & \\
\hline Product yields, vol\% of feed & & \\
\hline Hydrogen (FOE) & 0.45 & 0.67 \\
\hline Hydrogen sulfide (FOE) & 0.03 & 0.03 \\
\hline Methane (FOE) & 1.06 & 1.40 \\
\hline Ethylene (FOE) & 1.21 & 1.47 \\
\hline Ethane (FOE) & 0.74 & 0.98 \\
\hline C3 mixture & 13.63 & 15.72 \\
\hline C4 mixture & 18.37 & 19.25 \\
\hline Light naphtha & 51.33 & 48.42 \\
\hline Heavy naphtha & 9.03 & 8.54 \\
\hline Diesel & 17.70 & 17.52 \\
\hline Slurry & 4.75 & 4.71 \\
\hline & & \\
\hline Naphtha Properties: & & \\
\hline RON, light naphtha & 92.8 & 95.3 \\
\hline heavy naphtha & 87.1 & 79.6 \\
\hline MON, light naphtha & 82.8 & 11.1 \\
\hline & 77.1 & 0.135 \\
\hline heavy naphtha & 31.3 & 0.113 \\
\hline Oromatics, vol\% & 11.1 & \\
\hline Olefins, vol\% & & \\
\hline Utilities, per bbl of feed & 0.135 & \\
\hline Fuel, MMBtu/bbl & 0.038 & \\
\hline Steam, MLbs & 0.012 & \\
\hline Cooling water, MGals & & \\
\hline Catalyst and chemicals, $\$$ & & \\
\hline
\end{tabular}


Table C-7B - Catalytic cracking - DL1 heavy distillate

\begin{tabular}{|c|c|c|c|c|}
\hline Description & Neat & Neat & Hydrotreated & Hydrotreated \\
\hline Reactor temperature, ${ }^{\circ} \mathrm{F}$ & 975 & 975 & 1010 & 1010 \\
\hline Feed API & 22.5 & 22.5 & 23.3 & 23.3 \\
\hline \multicolumn{5}{|l|}{ Product yields, vol $\%$ of feed } \\
\hline Hydrogen (FOE) & 0.63 & 0.95 & 0.74 & 1.11 \\
\hline Hydrogen sulfide (FOE) & 0.001 & 0.00 & 0.003 & 0.003 \\
\hline Methane (FOE) & 0.64 & 0.93 & 0.74 & 1.07 \\
\hline Ethylene (FOE) & 0.79 & 0.98 & 0.86 & 1.08 \\
\hline Ethane (FOE) & 0.52 & 0.71 & 0.56 & 0.77 \\
\hline C3 mixture & 8.63 & 9.70 & 9.42 & 10.58 \\
\hline $\mathrm{C} 4$ mixture & 11.90 & 12.22 & 12.55 & 12.86 \\
\hline Light naphtha & 53.10 & 51.46 & 53.31 & 51.54 \\
\hline Heavy naphtha & 9.37 & 9.08 & 9.41 & 9.10 \\
\hline Diesel & 26.96 & 26.58 & 25.33 & 24.92 \\
\hline Slurry & 3.37 & 3.39 & 3.33 & 3.36 \\
\hline \multicolumn{5}{|l|}{ Naphtha Properties: } \\
\hline RON, light naphtha & 92.8 & 92.8 & 92.8 & 92.8 \\
\hline heavy naphtha & 87.1 & 87.1 & 87.1 & 87.1 \\
\hline MON, light naphtha & 82.8 & 82.8 & 82.8 & 82.8 \\
\hline heavy naphtha & 77.1 & 77.1 & 77.1 & 77.1 \\
\hline Aromatics, vol $\%$ & 31.3 & 31.3 & 31.3 & 31.3 \\
\hline Olefins, vol\% & 11.1 & 11.1 & 11.1 & 11.1 \\
\hline \multicolumn{5}{|l|}{ Utilities, per bbl of feed } \\
\hline Fuel, MMBtu/bbl & 0.200 & 0.182 & 0.199 & 0.181 \\
\hline Steam, MLbs & 0.038 & 0.038 & 0.038 & 0.038 \\
\hline Cooling water, MGals & 0.012 & 0.012 & 0.012 & 0.012 \\
\hline Catalyst and chemicals, $\$$ & 0.113 & 0.113 & 0.113 & 0.113 \\
\hline
\end{tabular}


Table C-7C - Catalytic cracking - DL2 heavy distillate

\begin{tabular}{|l|c|c|}
\hline Reactor outlet temperature & 975 & 1010 \\
\hline Feed API & 23.3 & 23.3 \\
\hline Product yields, vol\% of feed & & \\
\hline Hydrogen (FOE) & 0.57 & 1.04 \\
\hline Hydrogen sulfide (FOE) & 0.00 & 0.00 \\
\hline Methane (FOE) & 0.71 & 1.24 \\
\hline Ethylene (FOE) & 1.06 & 1.41 \\
\hline Ethane (FOE) & 0.52 & 0.79 \\
\hline C3 mixture & 11.29 & 13.02 \\
\hline C4 mixture & 14.27 & 14.80 \\
\hline Light naphtha & 57.21 & 55.26 \\
\hline Heavy naphtha & 10.10 & 9.75 \\
\hline Diesel & 19.38 & 17.97 \\
\hline Slurry & 3.57 & 3.56 \\
\hline & & \\
\hline Naphtha Properties: & & \\
\hline RON, light naphtha & 92.8 & 95.3 \\
\hline \multicolumn{1}{|c|}{ heavy naphtha } & 87.1 & 89.6 \\
\hline MON, light naphtha & 82.8 & 85.3 \\
\hline & 77.1 & 79.6 \\
\hline Aromatics, vol\% & 38.6 & 41.4 \\
\hline Olefins, vol\% & 4.7 & 5.4 \\
\hline & & \\
\hline Utilities, per bbl of feed & 0.135 & 0.135 \\
\hline Fuel, MMBtu/bbl & 0.038 & 0.038 \\
\hline Steam, MLbs & 0.012 & 0.012 \\
\hline Cooling water, MGals & 0.113 & 0.113 \\
\hline Catalyst and chemicals, \$ & & \\
\hline & & \\
\hline & & \\
\hline & & \\
\hline & & \\
\hline & & \\
\hline & & \\
\hline & & \\
\hline
\end{tabular}




\subsection{Appendix F - Product Slate and Pricing}

Table F-1 - Product slate and pricing

\begin{tabular}{|l|c|c|}
\hline & BPSD & \$/BBL \\
\hline LPG & & 12.66 \\
\hline & & \\
\hline Unleaded regular gasoline & 54,600 & 28.25 \\
\hline Unleaded premium gasoline & 18,200 & 29.16 \\
\hline Reformulated regular gasoline & 18,200 & 29.03 \\
\hline Reformulated premium gasoline & 6,070 & 29.76 \\
\hline & & \\
\hline Kerosene/Jet fuel & 12,840 & 19.36 \\
\hline No. 2 fuel oil & 13,100 & 19.08 \\
\hline Low sulfur diesel & 15,770 & 19.46 \\
\hline High sulfur diesel & 13,990 & 19.08 \\
\hline & & \\
\hline Low sulfur fuel oil & - & 17.70 \\
\hline & & \\
\hline Asphalt & - & 15.6 \\
\hline & & \\
\hline Anode-grade coke, short tons & & 35.00 \\
\hline Fuel-grade coke, short tons & & 3.00 \\
\hline Cat slurry & & \\
\hline Sulfur, long tons & & \\
\hline
\end{tabular}

